\title{
Effect of Ajwa Date Seed Powder on Inflammatory Response in High Fat Fed Sprague Dawley Female Rat
}

Farhana Yasmin Bhatti ${ }^{1}$, Fariha Ahmad Khan ${ }^{2}$, Abdul Mudabbir Rehan ${ }^{3}$, Zoobia Irum ${ }^{4}$, Sadia Chiragh ${ }^{5}$

${ }^{1}$ Medical Officer, Department of Gynaecology and Obstetrics, University of Lahore Teaching Hospital

${ }^{2}$ Assistant Professor, Department of Pharmacology, Akhtar Saeed Medical and Dental College, Lahore

${ }^{3}$ Assistant Professor, Department of Pharmacology, D. G. Khan Medical College, Punjab

${ }^{4}$ Assistant Professor, Department of Pharmacology, CMH Institute of Medical Sciences, Bahawalpur

${ }^{5}$ Professor, Department of Pharmacology, Al-Aleem Medical College, Lahore

\begin{tabular}{|c|c|c|}
\hline \multicolumn{3}{|c|}{ ABSTRACT } \\
\hline \multicolumn{3}{|c|}{$\begin{array}{l}\text { Background: Central obesity a worldwide metabolic and cosmetic problem poses significant health risk. Ajwa date seed } \\
\text { has antioxidant property and its high fiber content may prevent fat absorption and reduce fat deposition. The objective } \\
\text { of this research was to evaluate the effect of Ajwa date seed powder on visceral fat depots and inflammatory response } \\
\text { in high fat fed Sprague Dawley female rats. }\end{array}$} \\
\hline \multirow{2}{*}{\multicolumn{3}{|c|}{$\begin{array}{l}\text { Methodology: Thirty-six healthy rats of four weeks age were divided into three groups and followed for } 12 \text { weeks. Group } \\
\text { A (normal control) received regular diet. Group B (HFD control) received high fat diet, while group C (HFD+Ajwa group) } \\
\text { received high fat diet along with } 2 \% \text { Ajwa date seed powder. Body weight was measured weekly. Blood samples were } \\
\text { drawn for the estimation of serum IL- } 6 \text { and leptin levels by ELISA method at 12th week, after which, rats were } \\
\text { euthanized; perinephric fat was removed and weighed in grams. }\end{array}$}} \\
\hline & & \\
\hline \multirow{2}{*}{\multicolumn{3}{|c|}{$\begin{array}{l}\text { Results: HFD+Ajwa group gained less body weight as compared to HFD control group ( } p \text { value }=0.012 \text { ). There was a } \\
\text { remarkable reduction in perinephric fat weight ( } p \text { value } \leq 0.001 \text { ) and level of IL- } 6 \text { in HFD+Ajwa group }(p \text { value } \leq 0.001) \\
\text { as compared to HFD control. There was no significant difference in serum leptin level of the rats of all groups ( } p \text { value }= \\
0.567) \text {. }\end{array}$}} \\
\hline & & \\
\hline \multicolumn{3}{|c|}{$\begin{array}{l}\text { Conclusion: Ajwa date seed can prevent visceral adiposity and gain in body weight. Moreover, it has anti-inflammatory } \\
\text { effect; but no significant effect on satiety hormone. } \\
\text { Keywords: Ajwa date seed extract, Leptin, Obesity, Visceral fat. }\end{array}$} \\
\hline Authors' Contribution: & Correspondence: & \\
\hline & & \\
\hline
\end{tabular}

Cite this article. Bhatti FY, Khan FK, Rehan AM, Irum Z, Chiragh S. Effect of Ajwa Date Seed Powder on Inflammatory Response in High Fat Fed Sprague Dawley Female Rat. J Islamabad

Funding Source: PGMI, Lahore Med Dental Coll. 2021; 10(4):

\section{Introduction}

Obesity is a medical condition in which excessive body fat accumulates in the body to an extent that it may have a negative impact on health, leading to reduced life expectancy or increased risk of major health problems ${ }^{(1)}$. Statistically, obesity has increased at an alarming rate over the past several decades. In the past, it was considered a problem of high-income countries especially USA, but now it is widely spreading all over the world ${ }^{(2)}$. A national survey in USA showed that obesity epidemic began over 40 years ago and its prevalence has doubled from $1980-2010^{(3)}$. According to WHO, 1.9 billion adults who were greater than 18 years of age were overweight in 2016 and out of these, 650 million 
adults suffered from obesity. In Pakistan, $28 \%$ of men and $38 \%$ of women were obese according to a report of $2013^{(4)}$. Another study reported that $25 \%$ of adults were either obese or overweight ${ }^{(5)}$. In 2011, a health survey conducted in Pakistan showed that obesity is more prevalent in urban dwellers. ${ }^{(6)}$ Obesity is a multifactorial condition and it is predominantly caused by increasing trend in consumption of low-cost Westernized diet and adoption of sedentary lifestyle. There is a rich evidence-based literature that presents obesity as a complicated chronic medical condition caused by the interplay of genetic, environmental, metabolic, physical inactivity and behavioral factors ${ }^{(7)}$.

The primary step to reduce weight is dietary modification and adoption of active lifestyle. Low caloric intake with the increase in physical exercise shifts the positive energy balance into negative energy balance eventually causing reduction in the body weight ${ }^{(8,9)}$. Currently, the available therapeutic approaches for obesity management have numerous side effects except herbal medications. Therefore, growing attention has been given to natural products as they are not only rich in nutrition, vitamins and minerals but also a source of numerous phytochemicals ${ }^{(10)}$. Phoenix dactylifera $L$ plant has the highest rank among all the natural products used so far due to its nutritious value and historical background. Moreover, its medicinal potential as an anti-inflammatory, antihyperlipidemic and anti-diabetic agent is suggestive of anti-obesity effect. Its fruit (Ajwa date) seed contains rich amount of fiber and polyphenols ${ }^{(11)}$. The increase in dietary fiber intake can increase the amount of fat excreted in the stool as the soluble part of fiber binds to bile salts and affects the absorption of dietary fat from gut. The dietary fat is lost in stool instead of being absorbed from gut, that ultimately results in reduced accumulation in the body. Polyphenols are the naturally occurring bioactive phytochemical. Polyphenols modulate physiological and molecular pathways, that are involved in energy metabolism; adipocytes differentiation and $\beta$ - oxidation thus have antiobesity effect ${ }^{(12)}$. Polyphenols produce antiinflammatory effect by inhibiting the production of proinflammatory cytokine IL- 6 which is one of the major mediators of obesity induced inflammation (13).

There are limited clinical trials and little published information regarding the anti-obesity effect of herbs or natural products ${ }^{(14)}$. There are also limited local studies regarding anti-obesity effects of herbs. One local study done on Ethanolic extract of Cosmos caudatus Kaunth leaf showed anti-obesity effect in high fat diet rats ${ }^{(15)}$. Till now, no other local study is conducted regarding anti-obesity effect of herbs. In the current study, seed powder of Phoenix dactylifera $L$ (Ajwa date) has been used along with high fat diet to prevent the adiposity and inflammation in view of its richest proportion of polyphenols and fiber content.

\section{Methodology}

It was an experimental study conducted at Post Graduate Medical Institute Lahore from June to September 2017. Four weeks old female SpragueDawley rats, weighing 40-50g were taken and shifted to the animal house. Rats showing any signs of disease or altered behaviour were excluded from the study. Thirty-six female rats were randomly divided into three groups containing 12 rats in each group; Group A (normal control), Group B (HFD control) and Group C (HFD+Ajwa group). Calculated sample size using $90 \%$ power of study and $5 \%$ level of significance was 9 in each group but keeping in view the previous study design of similar published studies, we took a sample size of 12 in each group (16). They were kept in iron cages, 6 rats in each cage to avoid overcrowding. For one week, they were given normal chow for acclimatization. They had free access to food and water. The temperature was maintained in between 22-24 으 with natural day and night cycle. It was approved from Ethical Committee for Basic Sciences of PGMI 
Ajwa dates were purchased and its seeds were separated from flesh. Separated seeds were washed, remaining fruit pulp was removed and the seeds were air dried. When they were full dry, they were ground in electric grinder to powder form. Weight of seed powder was approximately $250 \mathrm{~g}$ obtained from $2 \mathrm{~kg}$ dates ${ }^{(17)}$.

High fat diet was prepared from fresh beef tallow. It was melted to oil in 5 hours and cooled down to room temperature. $210 \mathrm{~g}$ beef tallow oil was weighed in a glass container and mixed with $780 \mathrm{~g}$ of normal rat chow. $10 \mathrm{~g}$ sodium deoxycholate was also added to help in absorption of fat. After proper mixing of all the contents, feed was shaped into pellet ${ }^{(18)}$. These feed pellets were air dried and then stored into feed boxes. Diet for group C (HFD+Ajwa group) was prepared by adding $20 \mathrm{~g}$ of Ajwa date seed powder to $980 \mathrm{~g}$ of high fat diet ${ }^{(17)}$.

Before euthanizing the rats after 12 th week, $2 \mathrm{ml}$ blood sample was collected for serum markers testing. It was done by doing cardiac puncture. Then blood samples were put in yellow cap vacutainers (Biovac), allowed to clot and centrifuged at 2500 rpm for 10 minutes at room temperature for obtaining sera. Samples were stored in serum cups and kept at $-20^{\circ} \mathrm{C}$.

Rats were euthanized after taking the blood sample. Perinephric fat was removed, collected into airtight plastic bags and weighed in grams.

Study Variables were body weight (gm), serum IL-6 \& Leptin levels, perinephric fat weight and adiposomatic index. Rat's body weight was measured in grams in all study groups at day 0 , then weekly for 12 weeks. Concentration of serum IL- 6 and serum leptin was measured by enzyme linked immunosorbent assay (ELISA) technique. A rat specific research grade kit made by Glory Science Co.; USA was used. Adiposomatic index was calculated by dividing perinephric fat pad weight by body weight and multiplying with hundred.

After data collection, it was transcribed into computerized package i.e., Statistical Package for Social Sciences (SPSS 20). Kolmogorov-Smirnov test was applied to check the normal distribution of data. Necessary graphic representation was done by using Graph Pad Prism version 8. Quantitative variables were presented in form of mean \pm S.D. Analysis of Variance (ANOVA) was applied between three groups. Post hoc Tukey's test was applied for multiple comparisons in all groups. $p$ value of $\leq 0.05$ was considered significant.

\section{Results}

Body weights were almost similar at week zero in all the study groups. The body weight of animals belonging to all groups increased steadily from baseline till end of study. The body weight of HFD control was significantly higher than that of normal control as well as HFD+Ajwa group. Figure 1 illustrates the body weight of animals (Mean \pm SD) in all groups at the beginning and end of study.

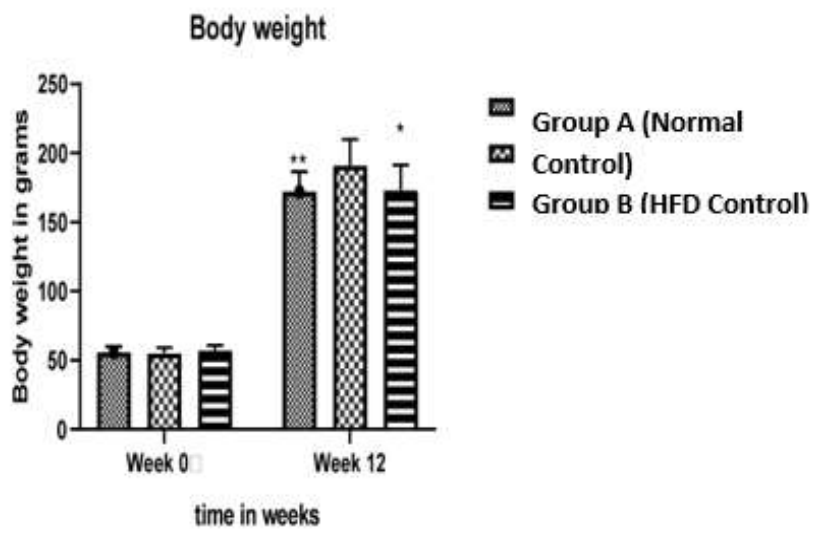

Figure. 1: Effect of Phoenix dactylifera $L$ seed powder on body weight

Level of serum IL-6 was highest in HFD Control followed by Normal Control whereas, HFD+Ajwa Group showed the lowest level. Multiple comparison by post hoc Tukey's test revealed that the level of IL6 in HFD+Ajwa Group was lower than that of HFD Control Group and the difference was statistically significant.

Serum Leptin level was highest in Normal Control followed by HFD+Ajwa Group while HFD Control showed the lowest level. No significant difference was observed between the mean values of all the groups by ANOVA with $p$ value of 0.567 (Table I) 


\begin{tabular}{|c|c|c|c|c|}
\hline \multicolumn{5}{|c|}{$\begin{array}{l}\text { Table I: Effect of Phoenix dactylifera L (Ajwa date) } \\
\text { seed powder on serum IL6 and leptin level of HFD } \\
\text { induced obese rats }(n=12) \text {. }\end{array}$} \\
\hline \multirow[t]{2}{*}{$\begin{array}{l}\text { Paramet } \\
\text { er }\end{array}$} & $\begin{array}{l}\text { Normal } \\
\text { Control }\end{array}$ & $\begin{array}{l}\text { HFD } \\
\text { Control }\end{array}$ & $\begin{array}{l}\text { HFD+Ajw } \\
\text { a Group }\end{array}$ & \multirow{2}{*}{$\begin{array}{l}\text { ANOV } \\
\text { A } \\
p \\
\text { value }\end{array}$} \\
\hline & $\begin{array}{l}\text { Mean } \quad \pm \\
\text { SD }\end{array}$ & $\begin{array}{l}\text { Mean } \pm \\
\text { SD }\end{array}$ & $\begin{array}{l}\text { Mean } \pm \\
\text { SD }\end{array}$ & \\
\hline $\begin{array}{l}\text { IL6 Level } \\
\text { (ng/L) }\end{array}$ & $\begin{array}{l}83 \pm 37.36 \\
* *\end{array}$ & $\begin{array}{l}108 \pm 44 . \\
56\end{array}$ & $\begin{array}{l}66 \pm 12.1^{*} \\
* *\end{array}$ & $0.02^{*}$ \\
\hline $\begin{array}{l}\text { Leptin ley } \\
(\mu \mathrm{g} / \mathrm{L})\end{array}$ & $\begin{array}{l}3.08 \pm 0.9 \\
2\end{array}$ & $\begin{array}{l}2.41 \pm 1.1 \\
2\end{array}$ & $\begin{array}{l}2.95 \pm 0.6 \\
8\end{array}$ & 0.567 \\
\hline
\end{tabular}

*P value $<0.05$

The perinephric fat weight and adiposomatic index of HFD Control Group were insignificantly higher than Normal Control Group, while that of HFD+Ajwa Group were significantly lower than HFD control as well as Normal Control Group (Table II)

\begin{tabular}{|c|c|c|c|c|}
\hline $\begin{array}{l}\text { Table. II: } \\
\text { seed po } \\
\text { \&Adiposor } \\
\text { obese rats }\end{array}$ & $\begin{array}{l}\text { ect of Pho } \\
\text { der on } \\
\text { atic index } \\
\text { =12). }\end{array}$ & $\begin{array}{l}\text { peri } \\
\text { Mea }\end{array}$ & $\begin{array}{l}\text { ic fat } \\
\text { of HFD }\end{array}$ & \\
\hline $\begin{array}{l}\text { Paramete } \\
r\end{array}$ & $\begin{array}{l}\text { Normal } \\
\text { Control }\end{array}$ & $\begin{array}{l}\text { HFD } \\
\text { Control }\end{array}$ & $\begin{array}{l}\text { HFD+Ajw } \\
\text { a Group }\end{array}$ & $\begin{array}{l}\text { ANOV } \\
\text { A }\end{array}$ \\
\hline & $\begin{array}{l}\text { Mean } \pm \\
\text { SD }\end{array}$ & $\begin{array}{l}\text { Mean } \\
\pm \text { SD }\end{array}$ & $\begin{array}{l}\text { Mean } \pm \\
\text { SD }\end{array}$ & $\begin{array}{l}\mathrm{p} \\
\text { value }\end{array}$ \\
\hline $\begin{array}{l}\text { Fat } \\
\text { weight (g) }\end{array}$ & $\begin{array}{l}4.3 \pm 1.32 \\
\# \#\end{array}$ & $\begin{array}{l}5.6 \pm 3.3 \\
0\end{array}$ & $\begin{array}{l}1.9 \pm 2.53 \\
* * *\end{array}$ & $\begin{array}{l}0.001^{*} \\
* *\end{array}$ \\
\hline $\begin{array}{l}\text { Adiposom } \\
\text { atic Index }\end{array}$ & $\begin{array}{l}2.54 \pm 0.7 \\
1 \# \#\end{array}$ & $\begin{array}{l}3.00 \pm 1 . \\
57\end{array}$ & $\begin{array}{l}1.1 \pm 0.32 \\
* * *\end{array}$ & $\begin{array}{l}0.001 * \\
* *\end{array}$ \\
\hline
\end{tabular}

\section{Discussion}

At the end of the study, highest weight was observed in HFD control followed by HFD+Ajwa group and normal control. The difference in body weight was statistically significant $(p=0.012)$. Similar results were observed in a local study done to evaluate the hypolipidemic effect of Ajwa date seed compared to simvastatin in butter fed dyslipidemic rats. Hypolipidemic effect was observed in the group which was given Ajwa date and there was also less weight gain in that group $(p \leq 0.05)$. Other inflammatory markers like IL- 6 and serum leptin was not assessed in that study ${ }^{(19)}$.
At the end of $12^{\text {th }}$ week, perinephric fat was resected, weighed and adiposomatic index was calculated. The HFD control rats had the largest amount of perinephric fat that was grossly appreciable, whereas HFD+Ajwa group rats had smaller amount of perinephric fat, even a few of them showed a negligible amount. Perinephric fat in HFD+Ajwa group was not only significantly less than HFD control but was less than normal control. These results propose that Ajwa date seed powder prevents the visceral fat deposition. Similar results were found in a Chinese study on the similar animal model through administration of green tea extract (contains the same active principal polyphenols) along with high fat diet in rats. The study with total green tea extracts, at a dose of 400 or $800 \mathrm{mg} / \mathrm{kg}$ were done on high-fat diet fed rats for 6 weeks to observe their anti-obesity effects. The results showed that polyphenols and polysaccharides were responsible for the suppressive effect of green tea extracts on body weight increase and fat accumulation ( $p$-value <0.05). Moreover, polyphenols, polysaccharides, or caffeine can improve blood lipid and antioxidant levels, effectively reducing rat serum leptin levels, and markedly reducing the expression levels of the IL- 6 and TNF- $\alpha$ gene ${ }^{(10)}$.

In our study, leptin level did decrease significantly. One local study also showed hypolipidemic effect of Ajwa date and Hallawi date and it was proposed that Ajwa date may have anti-obesity effect ${ }^{(18)}$. The mechanism could be that Ajwa seed powder contains $78-80 \%$ fiber content ${ }^{(23)}$ and the soluble fibers bind to bile salts secreted by the gallbladder into small intestine ${ }^{(20)}$. Another study also support our study, in which it was found that increased fiber intake in diet can increase the amount of fat secreted in the stool ${ }^{(21)}$. A study done in Gulf region was conducted to evaluate the antidiabetic, hypolipidemic and antioxidative activities of Ajwa date seed extract on streptozotocin induced diabetic rats. Administration of date seed extracts to diabetic rats caused a significant reduction in blood glucose 
level, oxidative stress and maintaining in the body weight. Serum leptin level and IL-6 was not analyzed in that study. ${ }^{(21)}$

In the current study, serum IL-6 level was measured as inflammatory marker at the end of $12^{\text {th }}$ week. Interleukin-6 is an immune mediator lymphokine protein that causes $B$ cell growth, activation and differentiation into plasma cells and antibodies which proceeds to inflammation. Usually this mediator is released from helper T-cell lymphocytes, but is also released from adipose tissue ${ }^{(22)}$. In the current study, it was observed that HFD control group showed highest level of IL- 6 as well as highest visceral fat amount indicating a possible link between adipose tissue and level of IL-6. Hence it can be concluded that IL- 6 level raised due to the presence of higher amount of visceral fat. On the other hand, the HFD+Ajwa group showed a marked reduction in the level of IL- 6 along with reduction in perinephric fat indicating that IL- 6 serum level is directly proportional to visceral fat amount. One study done in Indonesia on anti-inflammatory effect of dates seeds on carrageenan- induced edema in rats, showed decrease in several inflammatory mediators like IL-2, IL-1B, PGE-2, COX-1 and COX-2 (23). In our study, serum leptin was also analyzed at the end of 12 weeks to see the effect of Ajwa date seed powder on food intake. Leptin is a satiety hormone that is released from adipose tissue and regulates hunger by stimulating satiety center located on the lateral nucleus of hypothalamus ${ }^{(23)}$. On the other hand, elevated serum leptin level is observed in obese individuals which is considered to be due to development of leptin resistance ${ }^{(24)}$. In the current study, no difference was observed in serum leptin level of three study groups. One local study is done to evaluate the anti-obesity effect of Cosmos caudatus Kunth leaf in obesity induced high fat diet fed rats. Rats who received ethanolic extract of the leaf together with HFD showed significant $(p<0.05)$ reduction in body weight gain compared to rats receiving HFD only. Other related obesity biomarkers including plasma lipid profiles, insulin, leptin, ghrelin and adiponectin levels also showed significant improvement $(p<0.05)$. Administration of ethanolic leaf extract caused significant $(p<0.05)$ increase in fecal fat excretion ${ }^{(15)}$.

Highlight of our study is remarkable reduction of visceral fat in HFD+Ajwa group, not only from HFD group but also significantly less from normal control. Although visceral fat is smaller in quantity, but all the major health risks are associated with visceral fat ${ }^{(25)}$. It is a limitation of this study that phytochemical analysis was not performed, and proposal is based on results of other analytical studies. Other limitations of study are that neither food and calories intake were measured nor mechanism of fat loss was determined.

\section{Conclusion}

Addition of Ajwa date seed powder to diet can prevent weight gain and visceral adiposity but it has no significant effect on satiety hormone.

\section{Acknowledgement:}

Authors are thankful to staff of Animal House and Chemical Pathology Laboratory of Postgraduate Medical institute, Lahore for their cooperation.

\section{Disclaimer:}

Data is part of M. Phil thesis.

\section{References}

1. Bayliak MM, Abrat $O B$, Storey JM, Storey KB, Lushchak VI. Interplay between diet-induced obesity and oxidative stress: Comparison between Drosophila and mammals. Comp Biochem Physiol Part A Mol Integr Physiol. 2019;228:18-28. Doi: 10.1016/j.cbpa.2018.09.027

2. Malik VS, Willett WC, Hu FB. Global obesity: trends, risk factors and policy implications. Nat Rev Endocrinol. 2013;9(1):13-27. Doi: 10.1038/nrendo.2012.199

3. Finucane M, Stevens G, Cowan M, Danaei G, Lin J, Paciorek C, et al. Global Burden of Metabolic Risk Factors of Chronic Diseases Collaborating Group (Body Mass Index) National, regional, and global trends in body-mass index since 1980: systematic analysis of health examination surveys and epidemiological studies with 960 country-years and 9.1 million participants. Lancet. 2011;377(9765):55767. Doi: 10.1016/S0140-6736(10)62037-5 
4. Siddiqui $M$, Hameed $R$, Nadeem M, Mohammad T, Simbak N, Latif A, et al. Obesity in Pakistan; current and future perceptions. J Curr Trends Biomed Eng Biosci. 2018;17:1-4. Doi: 10.19080/CTBEB.2018.17.555958

5. Asif M, Aslam M, Altaf S, Atif S, Majid A. Prevalence and sociodemographic factors of overweight and obesity among Pakistani adults. J Obes Metab Syndr. 2020;29(1):58. Doi: 10.7570/jomes19039

6. Mushtaq MU, Gull S, Abdullah HM, Shahid U, Shad MA, Akram J. Prevalence and socioeconomic correlates of overweight and obesity among Pakistani primary school children. BMC Public Health. 2011;11(1):724. Doi: 10.1186/1471-2458-11-724

7. Upadhyay J, Farr O, Perakakis N, Ghaly W, Mantzoros C. Obesity as a disease. Med Clin North Am. 2018;102(1):13-33.Doi: 10.1016/j.mcna.2017.08.004

8. Westerterp KR. Exercise, energy balance and body composition. Eur J Clin Nutr. 2018;72(9):1246-50. Doi:10.1038/s41430-018-0180-4

9. Dhurandhar NV, Schoeller D, Brown AW, Heymsfield SB, Thomas D, Sørensen TI, et al. Energy balance measurement: when something is not better than nothing. Int J Obes. 2015;39(7):1109-13. Doi:10.1038/ijo.2014.199

10. Xu Y, Zhang M, Wu T, Dai S, Xu J, Zhou Z. The antiobesity effect of green tea polysaccharides, polyphenols and caffeine in rats fed with a high-fat diet. Food Funct. 2015;6(1):296-303. Doi: 10.1039/C4FO00970C

11. Khalid S, Khalid N, Khan RS, Ahmed H, Ahmad A. A review on chemistry and pharmacology of Ajwa date fruit and pit. Trends Food Sci Technol. 2017;63:60-69. Doi: 10.1016/j.tifs.2017.02.009

12. Boccellino M, D'Angelo S. Anti-obesity effects of polyphenol intake: current status and future possibilities. Int J Mol Sci. 2020;21(16):5642. Doi:10.3390/ijms21165642

13. Tangvarasittichai $S$, Pongthaisong $S$, Tangvarasittichai O. Tumor necrosis factor-A, interleukin-6, C-reactive protein levels and insulin resistance associated with type 2 diabetes in abdominal obesity women. Indian Ind J Clin Biochem. 2016;31(1):68-74. Doi: 10.1007/s12291-015-0514-0
14. Panigrahi T, Vishwas S, Dash D. A herbal approach to obesity Management: a review. Asian J Pharmaceut Educ Res. 2017;6:1-5. ISSN : 22787496

15. Rahman HA, Sahib NG, Saari N, Abas F, Ismail A, Mumtaz MW, et al. Anti-obesity effect of ethanolic extract from Cosmos caudatus Kunth leaf in lean rats fed a high fat diet. BMC Complement Altern Med. 2017;17(1):1-17. Doi: 10.1186/s12906-017-1640-4

16. An HM, Park SY, Lee DK, Kim JR, Cha MK, Lee SW, et al. Antiobesity and lipid-lowering effects of Bifidobacterium spp. in high fat diet-induced obese rats. Lipids Health Dis. 2011;10(1):116. Doi: 10.1186/1476-511X-10-116

17. Mushtaq Z, Kausar S, Kousar N, Chiragh S. EFFECT OF AJWA DATE SEED ON LIPID PROFILE OF DIET INDUCED HYPERLIPIDEMIC RABBITS. KMUJ. 2017;9(3):135-139

18. Hariri N, Thibault L. High-fat diet-induced obesity in animal models. Nutri Res Revi. 2010;23(2):270-99. Doi:10.1017/S095442241000016 8

19. Farooq Sultan SA, Saadia Shahzad Alam, Hassan Farooq, Ajmal Afzal, Moneeb Ashraf. Anti-Obesity and Hypolipidemic Effects of Ajwa Date Seed Compared to Simvastatin in Butter Fed Dyslipidemic Rats. Proceedings 2019;33(2):7.

20. Harvey R, Ferrier D. Illustrated Reviews: Biochemistry. Lippincott Williams \& Wilkins, Philadelphia; 2011:112-113

21. Slavin JL. Dietary fiber and body weight. Nutrition. 2005;21(3):411-8. Doi: 10.1016/j.nut.2004.08.018

22. Jones BE, Maerz MD, Buckner JH. IL-6: a cytokine at the crossroads of autoimmunity. Curr Opin Immunol. 2018;55:9-14. Doi: 10.1016/j.coi.2018.09.002

23. Kuryszko J, Slawuta P, Sapikowski G. Secretory function of adipose tissue. Pol J Vet Sci. 2016;19(2):441-446. Doi: 10.1515 / pjvs-2016-0056

24. Liu J, Yang X, Yu S, Zheng R. The leptin resistance. Neural Regulation of Metabolism: Springer; 2018:145-63. Doi: 10.1007/978-981-13-1286-1_8

25. Elffers TW, de Mutsert R, Lamb HJ, de Roos A, Willems van Dijk K, Rosendaal FR, et al. Body fat distribution, in particular visceral fat, is associated with cardiometabolic risk factors in obese women. PloS one. 2017;12(9):1-10. Doi: 10.1371/journal.pone.0185403 